\title{
Response of two Citrullus amarus accessions to isolates of three species of Meloidogyne and their graft compatibility with watermelon
}

\author{
Helio A. García-Mendívila , Maria Munera ${ }^{\mathrm{a}}$, Ariadna Ginéa ${ }^{\mathrm{a}}$, Nuria Escudero ${ }^{\mathrm{a}}$, Maria Belén Picób \\ Carmina Gisbert ${ }^{\mathrm{b}}$, Francisco Javier Sorribas ${ }^{\mathrm{a}, *}$ \\ a Department of Agri-Food Engineering and Biotechnology, Universitat Politècnica de Catalunya, Esteve Terradas 8, 08860, Castelldefels, Barcelona, Spain \\ ${ }^{\mathrm{b}}$ Institute for the Conservation and Breeding of Agricultural Biodiversity (COMAV), Universitat Politècnica de València, Spain
}

\section{A R T I C L E IN F O}

\section{Keywords:}

Citron melon

Citrullus lanatus

Cucurbits

Grafting

Plant resistance

Root-knot nematodes

\begin{abstract}
A B S T R A C T
The response of two Citrullus amarus accessions, BGV0005164 and BGV0005167, was assessed against different Meloidogyne arenaria, Meloidogyne incognita, and Meloidogyne javanica isolates in pot experiments and against $M$. incognita in plastic greenhouse. In the pot experiments, plants were inoculated with a second-stage juvenile per $\mathrm{cm}^{3}$ of sterile sand and maintained in a growth chamber at $25^{\circ} \mathrm{C}$ for 50 days. The watermelon cv. Sugar Baby was included as a susceptible control for comparison. At the end of the experiments, the number of egg masses and eggs per plant was determined, and the reproduction index was calculated as the percentage of the number of eggs produced in the $C$. amarus accessions with regard to that produced in the susceptible cv. Sugar Baby. In the plastic greenhouse experiment, the ungrafted watermelon cv. Sugar Baby and watermelons grafted onto each of the C. amarus accessions and onto the watermelon rootstock cv. Robusta were cultivated from May to August 2016 in plots with nematode densities from 46 to $1392 \mathrm{~J} 2$ per $250 \mathrm{~cm}^{3}$ of soil at transplantation. At the end of the experiment, the galling index and the number of eggs per plant were determined, and the reproduction index was calculated. Additionally, the compatibility of the two accessions with the watermelon cv. Sugar Baby and the effect on fruit quality (weight, size, shape, firmness, $\mathrm{pH}$, total soluble solids, and flesh color) were assessed under a hydroponic system in a greenhouse. The commercial rootstocks cv. Cobalt and cv. Robusta were also included. All the Meloidogyne isolates produced less egg masses and eggs per plant on the accessions than on Sugar Baby. Both accessions performed as resistant against $M$. arenaria, and from highly to moderately resistant to $M$. incognita and $M$. javanica in pot experiments. In the plastic greenhouse experiment, both $C$. amarus accessions performed as resistant to $M$. incognita. Both $C$. amarus accessions were compatible with the watermelon cv. Sugar Baby, but only the BGV0005167 accession did not influence the fruit quality. Then, the BGV0005167 accession is a promising rootstock for managing the three tropical root-knot nematode species without influencing watermelon fruit quality.
\end{abstract}

\section{Introduction}

Watermelon is one of the major cultivated cucurbit crops, with an estimated worldwide production of ca. 117 million $t$ from 3.5 million ha (FAOSTAT, 2016). As a result of the intensive cultivation in limited land resources, soilborne diseases and pests have significantly increased in recent years (Thies et al., 2015b). The root-knot nematode (RKN) Meloidogyne spp. is currently one of the main pathogens in cucurbit crops. Maximum yield losses of $88 \%$ in cu- cumber, $53 \%$ in zucchini, and $35 \%$ in watermelon cultivated under plastic greenhouses have been estimated in Spain (Giné et al., 2014; Vela et al., 2014; López-Gómez et al., 2014, 2015). The control of RKN has widely been done using fumigant and non fumigant nematicides (Nyczepir and Thomas, 2009). Nonetheless, the interest in nonchemical control alternatives has increased according to recent regulations such as the European Directive 2009/128/EC and the U.S. Clean Air Act (U.S. Environmental Protection Agency, 2012). In this scenario, plant resistance is a key tool for RKN man-

\footnotetext{
* Corresponding author.

Email address: francesc.xavier.sorribas@upc.edu (F.J. Sorribas)
} 
Table 1

Meloidogyne species and isolates used in pot experiments, geographic origin, and (a)virulence status against the $\mathrm{Mi} 1.2$ gene of tomato.

\begin{tabular}{|c|c|c|c|c|}
\hline $\begin{array}{l}\text { Meloidogyne } \\
\text { spp. }\end{array}$ & Isolate & $\begin{array}{l}\text { Geographic } \\
\text { origin }\end{array}$ & (a)virulence & Reference \\
\hline M. arenaria & MA68 & Barcelona & Avirulent & $\begin{array}{l}\text { Expósito et al. } \\
\text { (2018b) }\end{array}$ \\
\hline \multirow[t]{2}{*}{ M. incognita } & Agropolis & Barcelona & Avirulent & $\begin{array}{l}\text { Giné and } \\
\text { Sorribas (2017) }\end{array}$ \\
\hline & Garriga & Barcelona & Avirulent & $\begin{array}{l}\text { Expósito et al. } \\
\text { (2018b) }\end{array}$ \\
\hline \multirow[t]{4}{*}{ M. javanica } & MJ05 & Barcelona & Avirulent & $\begin{array}{l}\text { Ornat et al. } \\
\text { (2001) }\end{array}$ \\
\hline & Tugues & Barcelona & Avirulent & $\begin{array}{l}\text { Expósito et al. } \\
\text { (2018b) }\end{array}$ \\
\hline & Bay & Murcia & Avirulent & $\begin{array}{l}\text { Expósito et al. } \\
\text { (2018b) }\end{array}$ \\
\hline & MJLg & Almería & Virulent & $\begin{array}{l}\text { Expósito et al. } \\
\text { (2018b) }\end{array}$ \\
\hline
\end{tabular}

agement because it is an effective and economically profitable control method (Sorribas et al., 2005). Cropping resistant cultivars reduces the growth rate and the equilibrium density of the RKN population, as well as crop yield losses (Talavera et al., 2009). Moreover, it reduces crop yield losses of the following crop in the rotation scheme (Ornat et al., 1997; Thies et al., 2004; Westphal, 2011). Grafting onto resistant rootstocks is an alternative method to control soilborne pathogens when no commercial resistant cultivars are available (Yetişir et al., 2003; Miguel et al., 2004; Cohen et al., 2007; Lee and Oda, 2002; Thies et al., 2016). Regarding watermelon, it has been commonly grafted onto commercial rootstocks such as Cucurbita maxima x Cucurbita moschata and Lagenaria siceraria owing to their resistance to fusarium wilt. However, both rootstocks are susceptible to infection by Meloidogyne (Davis et al., 2008; Hassell et al., 2008; Thies et al., 2010, 2015a; Kokallis-Burelle and Rosskopf, 2011; López-Gómez et al., 2016; Giné et al., 2017). In the last few years, some accessions of citron melon, Citrullus lanatus var. citroides, most recently referred as Citrullus amarus (Chomicki and Renner, 2015), have been proven to be useful as watermelon rootstock. Indeed, these accessions provide resistance to fusarium wilt (Huitrón et al., 2007; Levi et al., 2017) and some RKN species in both greenhouse (Thies and Levi, 2003, 2007) and open field cultivation (Huitrón et al., 2007; Thies et al., 2010, 2015a, 2016). In addition, watermelon grafted onto $C$. amarus yielded more than those grafted onto L. siceraria, C. maxima x C. moschata or Praecitrullus fistulosus, without affecting the quality and the size of the fruits (Kyriacou et al., 2016; Thies et al., 2015a; Fredes et al., 2017). However, not all C. amarus accessions responded equally to RKN isolates (Thies and Levi, 2003, 2007; Thies et al., 2016; Levi et al., 2017), the screening of new accessions against local RKN populations being necessary to assure their efficacy. Furthermore, the compatibility with the scion and the effect on the quality of fruits is also required to be considered as a potential rootstock. The aim of this study was to characterize the response of two experimental $C$. amarus accessions against several isolates of Meloidogyne arenaria, Meloidogyne incognita and Meloidogyne javanica under controlled conditions and against M. incognita under plastic greenhouse conditions. Additionally, the compatibility of the two C. amarus accessions with the watermelon cv. Sugar Baby and the effect on fruit quality were assessed in a hydroponic system under greenhouse.

\section{Materials and methods}

\subsection{Nematode inoculum}

Seven isolates of $M$. arenaria, $M$. incognita and $M$. javanica were used in the experiments (Table 1). All the RKN isolates were maintained on the susceptible tomato cv. Durinta (Seminis Seeds, St. Louis, Missouri). Second-stage juveniles (J2) were used as the inoculum. The J2 were obtained from eggs of infected roots by maceration of roots using a $5 \%$ commercial bleach solution $(40 \mathrm{~g} / \mathrm{L} \mathrm{NaOCl})$ for $10 \mathrm{~min}$ according to the Hussey and Barker (1973) method. After maceration, the egg suspension was filtered through a $74 \mu \mathrm{m}$ sieve, and then, the eggs were collected on a $25 \mu \mathrm{m}$ sieve and placed on Baermann trays (Whitehead and Hemming, 1965). The J2 emerged during the first $24 \mathrm{~h}$ were discarded. After that, the $\mathrm{J} 2$ emerged were recovered every two days and maintained at $9^{\circ} \mathrm{C}$ until the pot experiments were carried out. The identification of the Meloidogyne species was confirmed using SCAR-PCR markers (Zijlstra et al., 2000).

\subsection{Response of C. amarus accessions to RKN isolates}

The C. amarus accessions BGV0005164 (CI64) and BGV0005167 (CI67), obtained from Institute for the Conservation and Breeding of Agricultural Biodiversity (COMAV-UPV) gene bank collection (Valencia, Spain), were assessed against the Meloidogyne isolates in three different pot experiments. In the first experiment, the accessions CI64 and CI67 were assessed against the Mi1.2 avirulent isolates Agropolis (M. incognita) and MJ05 (M. javanica). In the second experiment, the response of the two C. amarus accessions was assessed against the Mi1.2 avirulent isolates MA68 of $M$. arenaria; Agropolis and Garriga of $M$. incognita; and Bay, MJ05, and Tugues of M. javanica. In the third experiment, the response of both $C$. amarus accessions was assessed against the Mi1.2 virulent isolate MJLg of M. javanica. The watermelon cv. Sugar Baby (SB) (Intersemillas S. A., Loriguilla, Valencia, Spain) was included as susceptible control for comparison in all experiments. The watermelon rootstock cv. Robusta (RO) (C. lanatus, Intersemillas S. A., Loriguilla, Valencia, Spain) was also included for comparison as resistant control (López-Gómez et al., 2016) in the third experiment. Experiment 1 and 3 were carried out once, and each plant-RKN isolate combination was replicated 10 times. Experiment 2 was repeated once, and each plant-RKN isolate combination was replicated seven and eight times in the first and second experiment repetition, respectively.

All experiments were carried out following the same procedure. Briefly, seeds were germinated according to the method given in Expósito et al. (2018b). Seedlings were transplanted to $200 \mathrm{~cm}^{3}$ pots containing sterile sand and maintained in a growth chamber at $25 \pm 2{ }^{\circ} \mathrm{C}$ with a $16: 8 \mathrm{~h}$ (light:dark) photoperiod for a week and then inoculated with $1 \mathrm{~J} 2$ per $\mathrm{cm}^{3}$ soil. Plants were maintained in the growth chamber for 50 days. Plants were watered as needed throughout the experiment and fertilized with a slow-release fertilizer $\left(15 \% \mathrm{~N}, 9 \% \mathrm{P}_{2} \mathrm{O}_{5}, 12 \%\right.$ $\mathrm{K}_{2} \mathrm{O}, 2 \% \mathrm{MgO}_{2}$, microelements; Osmocote Plus). Soil temperatures were recorded daily at $30 \mathrm{~min}$ intervals with a PT100 probe (Campbell Scientific Ltd.) placed into the pots at $4 \mathrm{~cm}$ depth.

At the end of the experiments, the roots were carefully washed and weighed. Then, in the first and second experiments, the roots were submerged in $15 \mathrm{mg} / \mathrm{L}$ erioglaucine solution (Acros Organics) for $20 \mathrm{~min}$ to stain the egg masses before counting them (Omwega et al., 1988). In all experiments, eggs were extracted from roots by maceration in a $10 \%$ commercial bleach solution $(40 \mathrm{~g} / \mathrm{L} \mathrm{NaOCl})$ for 


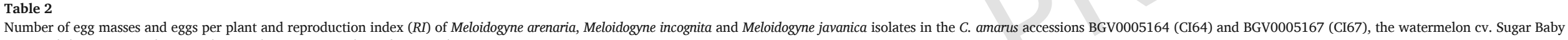
(SB), and the commercial rootstock cv. Robusta (RO) 50 days after inoculation in pot experiments.

\begin{tabular}{|c|c|c|c|c|c|c|c|c|c|c|c|c|}
\hline \multirow[t]{2}{*}{ Experiment } & \multirow[t]{2}{*}{ RKN species } & \multirow[t]{2}{*}{ Isolate } & \multicolumn{3}{|c|}{ Egg masses per plant } & \multicolumn{4}{|c|}{ Eggs per plant $\left(\mathrm{x} 10^{2}\right)$} & \multicolumn{3}{|l|}{$R I(\%)^{\mathrm{a}}$} \\
\hline & & & Cl64 & CI67 & SB & CI64 & CI67 & SB & RO & CI64 & CI67 & RO \\
\hline \multirow[t]{2}{*}{ Experiment 1} & M. incognita & Agropolis & $1.0 \pm 0.2 \mathrm{bA}$ & $1.0 \pm 0.7 \mathrm{bA}$ & $17.0 \pm 3.7$ a A & $3.5 \pm 1.6 \mathrm{~b} \mathrm{~A}$ & $4.6 \pm 3.2 \mathrm{~b} \mathrm{~A}$ & $126.9 \pm 26.7$ а A & & $2.7 \pm 1.3$ & $3.6 \pm 2.5$ & \\
\hline & M. javanica & MJ05 & $1.0 \pm 0.6 \mathrm{~b} \mathrm{~A}$ & $2.0 \pm 0.7 \mathrm{bA}$ & $25.0 \pm 0.2 \mathrm{a} \mathrm{A}$ & $8.7 \pm 8.2 \mathrm{bA}$ & $12.6 \pm 11 \mathrm{bA}$ & $180.5 \pm 32.5$ a A & & $4.8 \pm 4.5$ & $7.0 \pm 5.8$ & \\
\hline \multirow[t]{6}{*}{ Experiment 2} & M. arenaria & MA68 & $0.8 \pm 0.2 \mathrm{~b} \mathrm{~A}$ & $0.5 \pm 0.2 \mathrm{bA}$ & $5.0 \pm 1.2 \mathrm{a} \mathrm{A}$ & $2.1 \pm 0.8 \mathrm{~b} \mathrm{~A}$ & $1.1 \pm 0.6 \mathrm{bA}$ & $39.8 \pm 11.4$ a A & & $5.3 \pm 1.3$ & $2.8 \pm 1.5$ & \\
\hline & M. incognita & Agropolis & $0.5 \pm 0.4 \mathrm{~b} \mathrm{AB}$ & $0.1 \pm 0.1 \mathrm{bA}$ & $5.0 \pm 1.6 \mathrm{a} \mathrm{A}$ & $0.4 \pm 0.4 \mathrm{~b} \mathrm{AB}$ & $0.1 \pm 0.1 \mathrm{bA}$ & $23.9 \pm 13.7$ a $\mathrm{AB}$ & & $1.7 \pm 1.5$ & $0.5 \pm 0.5$ & \\
\hline & & Garriga & $0.3 \pm 0.1 \mathrm{~b} \mathrm{AB}$ & $0.2 \pm 0.1 \mathrm{bA}$ & $4.0 \pm 0.9 \mathrm{a} \mathrm{AB}$ & $0.1 \pm 0.1 \mathrm{bB}$ & $0.3 \pm 0.2 \mathrm{bA}$ & $12.2 \pm 3.5 \mathrm{a} \mathrm{AB}$ & & $0.5 \pm 0.3$ & $2.6 \pm 1.7$ & \\
\hline & M. javanica & Bay & $0.3 \pm 0.1 \mathrm{~b} \mathrm{AB}$ & $0.6 \pm 0.2 \mathrm{bA}$ & $6.0 \pm 1.7 \mathrm{a} \mathrm{A}$ & $0.2 \pm 0.1 \mathrm{~b} \mathrm{AB}$ & $0.3 \pm 0.1 \mathrm{bA}$ & $33.8 \pm 12.0$ a A & & $0.5 \pm 0.3$ & $0.9 \pm 0.4$ & \\
\hline & & MJ05 & $0.7 \pm 0.2 \mathrm{~b} \mathrm{AB}$ & $0.4 \pm 0.2 \mathrm{bA}$ & $5.0 \pm 1.0 \mathrm{a} \mathrm{A}$ & $1.2 \pm 0.8 \mathrm{~b} \mathrm{AB}$ & $1.0 \pm 0.8 \mathrm{bA}$ & $30.0 \pm 9.1 \mathrm{a} \mathrm{AB}$ & & $4.0 \pm 2.5$ & $3.2 \pm 2.8$ & \\
\hline & & Tugues & $0.1 \pm 0.1 \mathrm{bB}$ & $0.4 \pm 0.2 \mathrm{bA}$ & $1.0 \pm 0.1 \mathrm{a} \mathrm{B}$ & $0.5 \pm 0.5 \mathrm{bB}$ & $0.3 \pm 0.1 \mathrm{bA}$ & $3.7 \pm 1.7$ a B & & $14.3 \pm 13.5$ & $7.2 \pm 3.6$ & \\
\hline Experiment 3 & M. javanica & MJLg & na & na & na & $0.3 \pm 0.3 \mathrm{~b}$ & $0.7 \pm 0.6 \mathrm{~b}$ & $6.6 \pm 2.4 \mathrm{a}$ & $1.2 \pm 0.5 \mathrm{ab}$ & $5.0 \pm 5.0$ & $10.4 \pm 8.8$ & $17.5 \pm 8.1$ \\
\hline
\end{tabular}

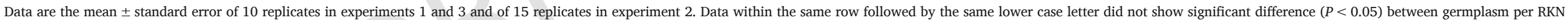

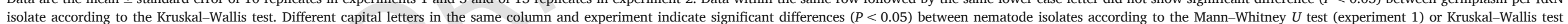

(experiment 2); na: not assessed.

a $R I$ (reproduction index) $=100 \times$ (number of eggs per plant produced in the $\mathrm{CI}$ accessions or RO/mean number of eggs per plant produced in the susceptible cv. Sugar Baby). 
Table 3

Galling index, eggs per plant and reproduction index $(R I)$ of $M$. incognita in the watermelon cv. Sugar Baby, the commercial watermelon rootstock cv. Robusta, and the C. amarus accessions BGV0005164 and BGV0005167 cultivated from May to August 2016 in plastic greenhouse at initial population densities from 46 to $1392 \mathrm{~J} 2$ per $250 \mathrm{~cm}^{3}$ of soil.

\begin{tabular}{llll}
\hline Plant host & $\begin{array}{l}\text { Galling } \\
\text { index }\end{array}$ & $\begin{array}{l}\text { Eggs per plant } \\
\left(\times 10^{2}\right)\end{array}$ & $\begin{array}{l}\text { Reproduction index } \\
(\%)^{\mathrm{b}}\end{array}$ \\
\hline Sugar Baby & $5.0 \pm 0.6 \mathrm{a}$ & $1031 \pm 484 \mathrm{a}$ & \\
Robusta & $2.8 \pm 0.4 \mathrm{~b}$ & $51 \pm 11 \mathrm{~b}$ & $4.4 \pm 0.9$ \\
BGV0005164 & $2.5 \pm 0.5 \mathrm{~b}$ & $16 \pm 10 \mathrm{~b}$ & $1.4 \pm 0.9$ \\
BGV0005167 & $1.5 \pm 0.5 \mathrm{~b}$ & $15 \pm 12 \mathrm{~b}$ & $1.3 \pm 1.0$ \\
\hline
\end{tabular}

Data are the mean \pm standard error of 10 replicates. Different letters in the same column indicate significant differences $(P<0.05)$ between germplasm according to the Kruskal-Wallis test.

a Galling index on a scale from 0 to 10 , where $0=$ complete and healthy root system and $10=$ plant and roots dead (Zeck, 1971).

b Reproduction index $=100 \times$ (number of eggs per plant produced in the CI accessions or Robusta/mean number of eggs per plant produced in the susceptible cv. Sugar Baby).

$10 \mathrm{~min}$ (Hussey and Barker, 1973), passed through a $74 \mu \mathrm{m}$ aperture screen and collected in a $25 \mu \mathrm{m}$ sieve for final counting. Reproduction index $(R I)$ was calculated as the percentage of eggs per plant produced in the experimental germplasm with regard to that in the susceptible one. The response of the accessions was categorized according to the $R I$ as highly resistant $(R I<1 \%)$, resistant $(1 \% \leq R I<10 \%)$, moderately resistant $(10 \% \leq R I<25 \%)$, slightly resistant $(25 \% \leq R I<50 \%)$, or susceptible $(R I \geq 50 \%)$ (Hadisoeganda and Sasser, 1982).

\subsection{Experiment under plastic greenhouse}

The experiment was carried out from May 10 to August 11, 2016, under a $700 \mathrm{~m}^{2}$ plastic greenhouse located at Viladecans (Barcelona, Spain), infested with the $M$. incognita isolate Agropolis. Ten $2.5 \mathrm{~m}$ long individual plots were used. Each plot was considered a replication and consisted in a row in which one plant each of ungrafted watermelon SB, the watermelon grafted onto CI64 and CI67, and that grafted onto the rootstock RO was transplanted with a space of $0.6 \mathrm{~m}$. Plants were arranged in such a way that every germplasm was an equal number of times at the edge of the plots and next to the susceptible SB. Plants were irrigated as needed through a drip irrigation system and weekly fertilized with a solution consisting of NPK (15-5-30) at $31 \mathrm{~kg} / \mathrm{ha}$ and iron chelate and micronutrients at $0.9 \mathrm{~kg} / \mathrm{ha}$. Plants were maintained for 20 weeks. The temperature was recorded at $30 \mathrm{~min}$ interval with temperature probes 5TM (Decagon Devices, Inc.) placed at a depth of $15 \mathrm{~cm}$ in the soil.

Nematode densities were determined at transplantation (Pi). Soil samples were taken from each experimental plot and consisted of eight cores taken from the first $30 \mathrm{~cm}$ of soil with an auger of diameter $2.5 \mathrm{~cm}$. Soil subsamples were mixed and passed through a $4 \mathrm{~mm}$ pore sieve to remove stones. The $\mathrm{J} 2$ were extracted from $500 \mathrm{~cm}^{3}$ of soil using Baermann trays (Whitehead and Hemming, 1965) and incubated at $27 \pm 2{ }^{\circ} \mathrm{C}$ for one week. Afterwards, the $\mathrm{J} 2$ were collected using a $25 \mu \mathrm{m}$ aperture screen, counted, and expressed as $\mathrm{J} 2$ per $250 \mathrm{~cm}^{3}$ of soil. At the end of the experiment, roots were carefully removed from the soil, washed, and weighed, and the galling index (GI) was evaluated on a scale from 0 to 10 , where $0=$ complete and healthy root system and $10=$ plants and roots dead (Zeck, 1971). After that, the number of eggs per plant was determined as described previously and was considered the final nematode density ( $P f$ ). $R I$ was calculated and the response of the $C$. amarus accessions and RO was categorized as described previously.

\subsection{Grafting compatibility and fruit quality}

The watermelon cultivar SB was self-grafted (SB-SB) and grafted onto CI64, CI67, RO, and the commercial hybrid C. maxima x C. moschata rootstock cv. Cobalt (CO) (Rijk Zwaan, BV, The Netherlands) according to the cleft procedure (Lee et al., 2010). Ten plants of each grafted combination were grown under a hydroponic system in a commercial greenhouse at Fundación Cajamar (Paiporta, Valencia) during the spring-summer 2018. The ungrafted watermelon SB was included for comparison. To evaluate the impact of grafting on fruit quality, ten fruits per treatment were characterized for the following traits: weight, length and width, rind and flesh thickness, flesh firmness (measured with a digital Penetrometer ( $8 \mathrm{~mm}$ ) FHT- $803^{\circledR}$, Melrose, MA), pH (measured with the $\mathrm{pH}$ indicator paper pH1-14; Merck, Darmstadt, Germany), total soluble solids (quantified using the digital refractometer Atago ${ }^{\circledR}$, Tokyo, Japan), and flesh color (measured with the colorimeter Minolta CR-400, New Jersey, USA) using the color parameters Hunter L, $a$ and $b$, where the $L$ value indicates lightness (from 0 to 100), a value indicates redness $(+)$ or greenness $(-)$, and $b$ value indicates yellowness $(+)$ or blueness $(-)$.

\subsection{Statistical analysis}

Statistical analyses were performed using R Statistical Software version 3.5.1 (R Foundation for Statistical Computing, Vienna, Austria). The data on the number of egg masses and eggs per plant were not normally distributed according to the normal Shapiro-Wilk $W$ test. Data from both repetitions of the second experiment were submitted to the nonparametric Mann-Whitney $U$ test and pooled together as replications of the same experiment because no differences were found $(P \geq 0.05)$. Comparisons between plant germplasm per each RKN isolate, as well as between RKN isolates per each plant germplasm within each experiment were done by the Mann-Whitney $U$ test (two groups) or the Kruskal-Wallis non parametric test (more than two groups). When significant $(P<0.05)$, medians were separated using pairwise multiple comparisons by the Dunn test $(P<0.05)$. Data on fruit quality traits of each grafted combination were compared to those of the ungrafted control SB by the Student t-test $(P<0.05)$.

\section{Results}

\subsection{Pot experiments}

The number of egg masses and eggs per plant was lower $(P<0.05)$ in both $C$. amarus accessions than in the watermelon SB, irrespective of the RKN isolate. Both $C$. amarus accessions responded as resistant $(1 \% \leq R I<10 \%)$ to the majority of the RKN isolates. The accession CI64 responded only as moderately resistant to the $M$. javanica isolate Tugues, and both CI67 and RO were moderately resistant to the Mi1.2 virulent MJLg isolate of $M$. javanica (Table 2).

\subsection{Experiment under plastic greenhouse}

The minimum and maximum soil temperatures during the experiment were $18.4^{\circ} \mathrm{C}$ and $30.5^{\circ} \mathrm{C}$, respectively. The initial nematode densities at transplantation ranged from 46 to $1392 \mathrm{~J} 2$ per $250 \mathrm{~cm}^{3}$ of soil. The number of eggs per plant and the galling index were significantly lower $(P<0.05)$ in both $C$. amarus accessions than those in the watermelon SB and the rootstock RO. Both $\mathrm{CI}$ ac- 
Table 4

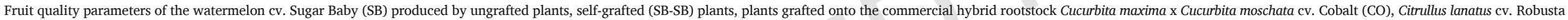
(RO), and the experimental Citrullus amarus accessions BGV0005167 (CI67) and BGV0005164 (CI64) cultivated under the hydroponic system in greenhouse.

\begin{tabular}{|c|c|c|c|c|c|c|c|c|c|c|c|}
\hline & Fruit size & & & Rind thickness (mm) & Flesh thickness $(\mathrm{cm})$ & Flesh firmness $\left(\mathrm{kg} \cdot \mathrm{cm}^{-2}\right)$ & Soluble solid $\left(\mathrm{Brix}^{0}\right)$ & $\mathrm{pH}$ & Color ${ }^{\mathrm{b}}$ & & \\
\hline Rootstock-scion & Weight $(\mathrm{kg})$ & Length $(\mathrm{cm})$ & Width (cm) & & $=$ & $\sqrt{2}$ & & & $L$ & $a$ & $b$ \\
\hline SB & $4.7 \pm 0.5^{\mathrm{a}}$ & $20.33 \pm 0.54$ & $21.10 \pm 0.44$ & $11.03 \pm 1.07$ & $18.77 \pm 0.11$ & $1.33 \pm 0.16$ & $10.67 \pm 0.32$ & $5.21 \pm 0.19$ & $33.38 \pm 1.35$ & $18.58 \pm 1.24$ & $12.03 \pm 0.34$ \\
\hline SB-SB & $5.0 \pm 0.3$ & $20.96 \pm 0.38$ & $21.47 \pm 0.23$ & $11.25 \pm 0.78$ & $18.87 \pm 0.27$ & $1.52 \pm 0.14$ & $10.03 \pm 0.23$ & $5.00 \pm 0.11$ & $30.09 \pm 1.61$ & $18.30 \pm 0.87$ & $11.00 \pm 1.01$ \\
\hline CO-SB & $5.5 \pm 0.2^{*}$ & $21.25 \pm 0.47$ & $21.95 \pm 0.38$ & $11.12 \pm 0.92$ & $19.50 \pm 0.35$ & $1.75 \pm 0.14$ & $9.45 \pm 0.27$ * & $5.38 \pm 0.16$ & $32.91 \pm 1.17$ & $20.63 \pm 1.07$ & $12.05 \pm 0.54$ \\
\hline RO-SB & $5.1 \pm 0.3$ & $20.85 \pm 0.38$ & $21.32 \pm 0.33$ & $12.92 \pm 0.73$ & $18.65 \pm 0.27$ & $1.62 \pm 0.11$ & $10.02 \pm 0.22$ & $5.0 \pm 0.17$ & $31.29 \pm 0.78$ & $18.94 \pm 0.38$ & $11.49 \pm 0.33$ \\
\hline CI64-SB & $5.2 \pm 0.2$ & $21.42 \pm 0.38$ & $21.55 \pm 0.31$ & $14.04 \pm 0.75^{*}$ & $18.4 \pm 0.29$ & $1.76 \pm 0.12^{*}$ & $9.77 \pm 0.22$ * & $5.00 \pm 0.13$ & $31.94 \pm 0.96$ & $19.08 \pm 0.87$ & $11.98 \pm 0.44$ \\
\hline CI67-SB & $5.0 \pm 0.2$ & $20.93 \pm 0.31$ & $21.38 \pm 0.25$ & $12.89 \pm 0.62$ & $18.54 \pm 0.24$ & $1.62 \pm 0.09$ & $10.3 \pm 0.18$ & $5.17 \pm 0.13$ & $32.80 \pm 0.88$ & $19.03 \pm 0.71$ & $12.18 \pm 0.36$ \\
\hline
\end{tabular}

a Data are the mean \pm standard error of 10 replicates. Date in the same column followed by * indicate significant differences $(P<0.05)$ with regard to the ungrafted watermelon cv. Sugar Baby (SB) according to Student's t-test.

b Color: parameters measured in fruit flesh: Hunter L, lightness (from 0 to 100); a, red (+); b, yellow (+) or blue (-) 
cession and the rootstock RO performed as resistant $(1 \% \leq R I<10 \%)$ to M. incognita. (Table 3).

\subsection{Grafted compatibility and fruit quality}

Under our experimental conditions, both ungrafted watermelon SB and watermelon SB grafted onto different rootstocks showed a similar growth performance. However, some effects of fruit traits were observed in plants grafted onto specific rootstocks (Table 4). The weight of watermelon fruits produced by SB onto the Cucurbita hybrid rootstock $\mathrm{CO}$ was greater $(P<0.05)$ than the weight of those produced by the ungrafted plants ( $5.5 \pm 0.2$ vs. $4.7 \pm 0.5 \mathrm{~kg}$ ) but with a significant decrease $(P<0.05)$ of soluble solids $\left(9.45 \pm 0.27\right.$ vs. $\left.10.67 \pm 0.32{ }^{\circ} \mathrm{Bx}\right)$. The watermelon rootstocks RO and CI67 did not influence the fruit traits compared to those produced by the ungrafted and self-grafted SB, but the rootstock CI64 produced fruits with thicker rinds, firmer flesh, and less soluble solids $(P<0.05)$ (Table 4$)$.

\section{Discussion}

The results of this study showed that the C. amarus accessions CI64 and CI67 are resistant to several nematode isolates belonging to the three most widespread RKN species. Some other C. amarus accessions resistant to RKN have been reported previously (Huitrón et al., 2007; Thies et al., 2015c), thus increasing the number of accessions that could be used as putative watermelon rootstock. The watermelon has been described as a poor host of Meloidogyne owing to its low values of maximum multiplication rate and equilibrium density (López-Gómez et al., 2014). The RKN isolates assessed in this study reproduced less than $10 \%$ in both C. amarus accessions compared to that in the watermelon cv. Sugar Baby in both pot and plastic greenhouse experiments, which demonstrates their potential for suppressing the RKN population growth rate. Other $C$. amarus accessions and lines have also been shown to be RKN resistant under field and plastic greenhouse conditions (Huitrón et al., 2007; Thies et al., 2008, 2009, 2015a, 2015b, 2015c). The resistance of $C$. amarus to RKN has been associated with the relatively high root fibrosity compared to that of $C$. lanatus var. lanatus, Citrullus colocynthis, L. siceraria, and C. maxima x C. moschata (Thies and Levi, 2003, 2007; Thies et al., 2015c, 2016).

Interestingly, both $C$. amarus accessions assessed in this study were also resistant to a Mi1.2 gene virulent isolate. This finding shows the usefulness to include this germplasm as a component of the rotation scheme for managing virulent RKN isolates for specific resistance genes. The most available resistance genes to RKN in vegetables are in solanaceous cultivars and rootstocks, e.g., tomato and pepper. The virulence to a given R-gene could be counter-selected by other R-genes because it is highly specific and it has a fitness cost to be acquired (Djian-Caporalino et al., 2011). Recently, some Cucumis metuliferus accessions have been described as resistant to Mi1.2 gene virulent RKN isolates (Expósito et al., 2018a), and although the selection for virulence to the Mi1.2 gene was not prevented when alternated with tomato grafted onto the resistant rootstock cv. Aligator, it influenced its level (Expósito et al., $2018 \mathrm{~b})$. The availability of some more sources of resistance used in rotation schemes could favor the durability of specific resistant genes by preventing the fixation of the virulence character in the RKN population.

Grafting commercial watermelon cultivars onto resistant rootstocks has proven to be a successful approach to manage plant diseases, being a widely accepted practice in some parts of the world (Oda, 2002; Miguel et al., 2004; Cohen et al., 2007; Yetişir et al.,
2007; Leonardi et al., 2017). Cucurbita hybrids, the most popular watermelon rootstocks, are resistant to some soil-borne fungal diseases but susceptible to RKN (López-Gómez et al., 2016; Giné et al., 2017). The results of this study showed that both $C$. amarus accessions are able to suppress RKN at the same level as that of the commercial C. lanatus cv. Robusta. In addition, these two experimental accessions have also been proved to be moderately to highly resistant to Fusarium oxysporum f. sp. niveum (Fon) races 0 and 2 (Garcés et al., personal communication), which improve their success as watermelon rootstock. Some other C. amarus accessions also showed resistance to other diseases such as gummy stem blight (Gusmini et al., 2005), powdery mildew (Davis et al., 2007; Tetteh et al., 2010), and potyviruses (Guner, 2004; Strange et al., 2002; Guner and Wehner, 2008).

Both $C$. amarus accessions have shown efficient grafting compatibility to watermelon, but they differed in influencing the fruit quality. While the quality of fruit produced by the watermelon grafted onto the CI67 accession did not show significant difference from that produced by the ungrafted and self-grafted plants, it did show a significant difference when grafted onto CI64. Similar results were obtained with the watermelon F1 hybrid cv. Oneida onto CI67 (Fredes et al., 2017). This previous study also showed that the citron melon accession affected the aroma of the watermelon flesh less than the hybrid Cucurbita rootstock, which, in turn, produced larger fruit with less soluble solids.

\section{Conclusion}

The C. amarus accession CI67 is a promising rootstock for managing the three tropical RKN species without influencing watermelon fruit quality.

\section{Acknowledgments}

The authors thank MINECO and FEDER for funding projects AGL2013-49040-C2-1-R, AGL2014-53398-C2-2-R-AR, AGL2017-89785-R, and AGL2017-85563-C2-1-R-AR. H. A. García-Mendívil acknowledges CONACYT for suport through a pre-doctoral grant.

\section{References}

Chomicki, G., Renner, S.S., 2015. Watermelon origin solved with molecular phylogenetics including Linnaean material: another example of museomics. New Phytol. 205 (2), 526-532 https://doi.org/10.1111/nph.13163.

Cohen, R., Burger, Y., Horev, C., Koren, A., 2007. Introducing grafted cucurbits to modern agriculture: the Israeli experience. Plant Dis. 91 (8), 916-923 https://doi.org/10. 1094/PDIS-91-8-0916.

Davis, A.R., Levi, A., Tetteh, A., Wehner, T., Russo, V., Pitrat, M., 2007. Evaluation of watermelon and related species for resistance to race $1 \mathrm{~W}$ Powdery Mildew. J. Am. Soc. Hortic. Sci. 132 (6), 790-795.

Davis, A.R., Perkins-Veazie, P., Sakata, Y., López-Galarza, S., Maroto, J.V., Lee, S.G., Huh, Y.C., Sun, Z., Miguel, A., King, S.R., 2008. Cucurbit grafting. Crit. Rev. Plant Sci. 27 (1), 50-74 https://doi.org/10.1080/07352680802053940.

Djian-Caporalino, C., Molinari, S., Palloix, A., Ciancio, A., Fazari, A., Marteu, N., Ris, N., Castagnone-Sereno, P., 2011. The reproductive potential of the root-knot nematode Meloidogyne incognita is affected by selection for virulence against major resistance genes from tomato and pepper. Eur. J. Plant Pathol. 131 (3), 431-440 https://doi.org/ 10.1007/s10658-011-9820-4.

Expósito, A., García, S., Giné, A., Escudero, N., Sorribas, F.J., 2018a. Cucumis metuliferus reduces Meloidogyne incognita virulence against the Mi1.2 resistance gene in a tomato-melon rotation sequence. Pest Manag. Sci. https://doi.org/10.1002/ps.5297.

Expósito, A., Munera, M., Giné, A., López-Gómez, M., Cáceres, A., Picó, B., Gisbert, C., Medina, V., Sorribas, F.J., 2018b. Cucumis metuliferus is resistant to root-knot nematode Mi1.2 gene (a) virulent isolates and a promising melon rootstock. Plant Pathol. 67 (5), 1161-1167 https://doi.org/10.1111/ppa.12815.

FAOSTAT, 2016. Food and Agriculture Organization of the United Nations. Statistics Division, Accessed in August/2018. www.fao.org/faostat/.

Fredes, A., Roselló, S., Beltrán, J., Cebolla-Cornejo, J., Pérez-de-Castro, A., Gisbert, C., Picó, M.B., 2017. Fruit quality assessment of watermelons grafted onto citron melon rootstock. J. Sci. Food Agric. 97 (5), 1646-1655 https://doi.org/10.1002/jsfa.7915. 
Giné, A., González, C., Serrano, L., Sorribas, F.J., 2017. Population dynamics of Meloidogyne incognita on cucumber grafted onto the Cucurbita hybrid RS841 or ungrafted and yield losses under protected cultivation. Eur. J. Plant Pathol. 148 (4), 795-805 https: //doi.org/10.1007/s10658-016-1135-z.

Giné, A., López-Gómez, M., Vela, M.D., Ornat, C., Talavera, M., Verdejo-Lucas, S., Sorribas, F.J., 2014. Thermal requirements and population dynamics of root-knot nematodes on cucumber and yield losses under protected cultivation. Plant Pathol. 63 (6), 1446-1453 https://doi.org/10.1111/ppa.12217.

Giné, A., Sorribas, F.J., 2017. Effect of plant resistance and BioAct WG (Purpureocillium lilacinum strain 251) on Meloidogyne incognita in a tomato-cucumber rotation in a greenhouse. Pest Manag. Sci. 73 (5), 880-887 https://doi.org/10.1002/ps.4357.

Guner, N., 2004. Papaya Ringspot Virus Watermelon Strain and Zucchini Yellow Mosaic Virus Resistance in Watermelon. Ph.D Diss Department of Horticultural Sciences, North Carolina State Univ., Raleigh, NC https://repository.lib.ncsu.edu/handle/1840. $16 / 3271$.

Guner, N., Wehner, T.C., 2008. Overview of potyvirus resistance in watermelon. In: Proc. IXth EUCARPIA Meeting Cucurbitaceae (Avignon, France). Institut National de la Recherche Agronomique, Avignon, France, pp. 445-451, 21-24 May 2008.

Gusmini, G., Song, R., Wehner, T., 2005. New sources of resistance to gummy stem blight in watermelon. Crop Sci. 45, 582-588 https://doi.org/10.2135/cropsci2005.0582.

Hadisoeganda, W.W., Sasser, J.N., 1982. Resistance of tomato, bean, southern pea, and garden pea cultivars to root-knot nematodes based on host suitability. Plant Dis. 66 (2), 145-150.

Hassell, R.L., Memmott, F., Liere, D.G., 2008. Grafting methods for watermelon production. Hortscience 43 (6), 1677-1679.

Huitrón, M.V., Diaz, M., Diánez, F., Camacho, F., 2007. The effect of various rootstocks on triploid watermelon yield and quality. J. Food Agric. Environ. 5 (3/4), 344.

Hussey, R.S., Barker, K., 1973. A comparison of methods of collecting inocula of Meloidogyne spp., including a new technique. Plant Dis. Rep. 57, 1025-1028.

Kokallis-Burelle, N., Rosskopf, E.N., 2011. Microplot evaluation of rootstocks for control of Meloidogyne incognita on grafted tomato, muskmelon, and watermelon. J. Nematol. 43 (3-4), 166.

Kyriacou, M.C., Soteriou, G.A., Rouphael, Y., Siomos, A.S., Gerasopoulos, D., 2016. Configuration of watermelon fruit quality in response to rootstock-mediated harvest maturity and postharvest storage. J. Sci. Food Agric. 96 (7), 2400-2409 https://doi.org/ $10.1002 /$ jsfa.7356.

Lee, J.M., Oda, M., 2002. Grafting of herbaceous vegetable and ornamental crops. Hortic. Rev. 28, 61-124 https://doi.org/10.1002/9780470650851.ch2.

Lee, J.M., Kubota, C., Tsao, S.J., Bie, Z., Echevarria, P.H., Morra, L., Oda, M., 2010. Current status of vegetable grafting: diffusion, grafting techniques, automation. Sci. Hortic. (Amst.) 127 (2), 93-1 https://doi.org/10.1016/j.scienta.2010.08.003

Leonardi, C., Kyriacou, M., Gisbert, C., Oztekin, G.B., Mourão, I., Rouphael, Y., 2017. Quality of grafted vegetables. In: Colla, G., Pérez-Alfocea, F., Schwarz, D. (Eds.), Vegetable Grafting: Principles and Practices. CAB International, Oxfordshire, UK, pp. 216-244 https://doi.org/10.1079/9781780648972.0000.

Levi, A., Jarret, R., Kousik, S., Wechter, W.P., Nimmakayala, P., Reddy, U.K., 2017. Genetic resources of watermelon. In: Genetics and Genomics of Cucurbitaceae. Springer, pp. 87-110 https://doi.org/10.1007/7397_2016_34.

López-Gómez, M., Flor-Peregrín, E., Talavera, M., Sorribas, F.J., Verdejo-Lucas, S., 2015. Population dynamics of Meloidogyne javanica and its relationship with the leaf chlorophyll content in zucchini. Crop Protect. 70, 8-14 https://doi.org/10.1016/j. cropro.2014.12.015

López-Gómez, M., Gine, A., Vela, M.D., Ornat, C., Sorribas, F.J., Talavera, M., Verdejo-Lucas, S., 2014. Damage functions and thermal requirements of Meloidogyne javanica and Meloidogyne incognita on watermelon. Ann. Appl. Biol. 165 (3), 466-473 https: //doi.org/10.1111/aab.12154.

López-Gómez, M., Talavera, M., Verdejo-Lucas, S., 2016. Differential reproduction of Meloidogyne incognita and M. javanica in watermelon cultivars and cucurbit rootstocks. Plant Pathol. 65 (1), 145-153 https://doi.org/10.1111/ppa.12394.

Miguel, A., Maroto, J.V., San Bautista, A., Baixauli, C., Cebolla, V., Pascual, B., López, S., Guardiola, J.L., 2004. The grafting of triploid watermelon is an advantageous alternative to soil fumigation by methyl bromide for control of Fusarium wilt. Sci. Hortic. (Amst.) 103 (1), 9-17 https://doi.org/10.1016/j.scienta.2004.04.007.

Nyczepir, A.P., Thomas, S.H., 2009. Current and future management strategies in intensive crop production systems. Root-knot nematodes. In: Perry, R.N., Moens, M., Starr, J.L. (Eds.), Root-knot Nematodes. CABI, pp. 412-443.

Oda, M., 2002. Grafting of vegetable crops. Sci. Rep. Agric. Biol. Sci., Osaka Pref. Univ. $54,49-72$.

Omwega, C.O., Thomason, I.J., Roberts, P.A., 1988. A nondestructive technique for screening bean germplasm for resistance to Meloidogyne incognita. Plant Dis. 72, 970-972.
Ornat, C., Verdejo-Lucas, S., Sorribas, F.J., 1997. Effect of the previous crop on population densities of Meloidogyne javanica and yield of cucumber. Nematropica 27, 85-90.

Ornat, C., Verdejo-Lucas, S., Sorribas, F.J., 2001. A population of Meloidogyne javanica in Spain virulent to the Mi resistance gene in tomato. Plant Dis. 85 (3), 271-276 https: //doi.org/10.1094/PDIS.2001.85.3.271.

Sorribas, F.J., Ornat, C., Verdejo-Lucas, S., Galeano, M., Valero, J., 2005. Effectiveness and profitability of the Mi-resistant tomatoes to control root-knot nematodes. Eur. J. Plant Pathol. 111 (1), 29-38 https://doi.org/10.1007/s10658-004-1982-x.

Strange, E.B., Guner, N., Pesic-VanEsbroeck, Z., Wehner, T.C., 2002. Screening the watermelon germplasm collection for resistance to papaya ringspot virus type-W. Crop Sci. $32,1324-1330$.

Talavera, M., Verdejo-Lucas, S., Ornat, C., Torres, J., Vela, M.D., Macias, F.J., Cortada, L., Arias, D.J., Valero, J., Sorribas, F.J., 2009. Crop rotations with Mi gene resistant and susceptible tomato cultivars for management of root-knot nematodes in plastic houses. Crop Protect. 28 (8), 662-667 https://doi.org/10.1016/j.cropro.2009.03.015.

Tetteh, A.Y., Wehner, T.C., Davis, A.R., 2010. Identifying resistance to powdery mildew race $2 \mathrm{~W}$ in the USDA-ARS watermelon germplasm collection. Crop Sci. 50, 933-939.

Thies, J.A., Ariss, J., Kousik, C.S., Hassell, R., 2008. Grafting-a tool for managing root-knot nematodes in watermelon. Phytopathology 98, S156.

Thies, J.A., Ariss, J., Hassell, R., Olson, S., 2009. Grafting for management of root-knot nematodes in watermelon. Hortscience 44 (3), 576.

Thies, J.A., Ariss, J.J., Hassell, R.L., Olson, S., Kousik, C.S., Levi, A., 2010. Grafting for management of southern root-knot nematode, Meloidogyne incognita, in watermelon. Plant Dis. 94 (10), 1195-1199 https://doi.org/10.1094/PDIS-09-09-0640.

Thies, J.A., Ariss, J.J., Hassell, R.L., Buckner, S., Levi, A., 2015a. Accessions of Citrullus lanatus var. citroides are valuable rootstocks for grafted watermelon in fields infested with root-knot nematodes. Hortscience 50 (1), 4-8.

Thies, J.A., Ariss, J.J., Kousik, C.S., Hassell, R.L., Levi, A., 2016. Resistance to southern root-knot nematode (Meloidogyne incognita) in wild watermelon (Citrullus lanatus var. citroides). J. Nematol. 48 (1), 14.

Thies, J.A., Buckner, S., Horry, M., Hassell, R., Levi, A., 2015b. Influence of Citrullus lanatus var. citroides rootstocks and their F1 hybrids on yield and response to root-knot nematode, Meloidogyne incognita, in grafted watermelon. Hortscience 50 (1), 9-12.

Thies, J.A., Davis, R.F., Mueller, J.D., Fery, R.L., Langston, D.B., Miller, G., 2004. Double-cropping cucumbers and squash after resistant bell pepper for root-knot nematode management. Plant Dis. 88 (6), 589-593 https://doi.org/10.1094/PDIS.2004.88 6.589

Thies, J.A., Levi, A., 2003. Resistance of watermelon germplasm to the peanut root-knot nematode. Hortscience 38 (7), 1417-1421.

Thies, J.A., Levi, A., 2007. Characterization of watermelon (Citrullus lanatus var. citroides) germplasm for resistance to root-knot nematodes. Hortscience 42 (7), 1530-1533.

Thies, J.A., Levi, A., Ariss, J.J., Hassell, R.L., 2015c. RKVL-318, a root-knot nematode-resistant watermelon line as rootstock for grafted watermelon. Hortscience 50 (1), $141-142$.

U.S. Environmental Protection Agency, 2012. Ozone Layer Protection, Accessed in August/ 2018 https://www.epa.gov/ozone-layer-protection/.

Vela, M.D., Giné, A., López-Gómez, M., Sorribas, F.J., Ornat, C., Verdejo-Lucas, S., Talavera, M., 2014. Thermal time requirements of root-knot nematodes on zucchini-squash and population dynamics with associated yield losses on spring and autumn cropping cycles. Eur. J. Plant Pathol. 140 (3), 481-490 https://doi.org/10.1007/ s10658-014-0482-x.

Westphal, A., 2011. Sustainable approaches to the management of plant-parasitic nematodes and disease complexes. J. Nematol. 43 (2), 122.

Whitehead, A.G., Hemming, J.R., 1965. A comparison of some quantitative methods of extracting small vermiform nematodes from soil. Ann. Appl. Biol. 55 (1), 25-38.

Yetişir, H., Kurt, , Sari, N., TOK, F.M., 2007. Rootstock potential of Turkish Lagenaria siceraria germplasm for watermelon: plant growth, graft compatibility, and resistance to Fusarium. Turk. J. Agric. For. 31 (6), 381-388.

Yetișir, H., Sari, N., Yücel, S., 2003. Rootstock resistance to Fusarium wilt and effect on watermelon fruit yield and quality. Phytoparasitica 31 (2), 163-169 https://doi.org/ $10.1007 /$ BF02980786.

Zeck, W.M., 1971. Rating scheme for field evaluation of root-knot nematode infestations. Pflanzenschutz nachrichten. Bayer. 24, 141-144.

Zijlstra, C., Donkers-Venne, D.T., Fargette, M., 2000. Identification of Meloidogyne incognita, M. javanica and M. arenaria using sequence characterised amplified region (SCAR) based PCR assays. Nematology 2 (8), 847-853 https://doi.org/10.1163/ 1568541007501 